\title{
AESTHETIC POLARITIES: URBAN CREATIVITY AND CITY DWELLING. INTRODUCTION
}

The title of this volume - Aesthetic Polarities: Urban Creativity and City Dwelling - automatically directs our attention to contrasts and disparities encountered in modern cities. Visual contrasts first come to mind: between what is neat, revitalized and frequently visited, and what is destroyed, degraded and forgotten. However, the articles in this volume address the issue of aesthetic polarization in a deeper perspective of the city's experience. They focus on everyday experience, including that which is stimulated by the engaged and radical activity of both residents, activists, researchers and artists representing various fields of art: urban planners, architects, multimedia artists. They present also various endeavors to combine the potential of urban creativity resulting from the historical and urban heritage with the continuity of experience and practice of living.

At the same time these articles join the discussion on the inseparable pair of concepts of revitalization and participation which has been going on for several generations of authors, among which probably the hottest names are: Jan Gehl, Manuel Castells, Sahron Zukin, Chantal Mouffe, Marcus Miessen and Justin McGuirk. Our authors, however, focus not on polemic itself, but on specific solutions. These are both successful and developing projects over the years (Remesar, Angosto) and concrete particulars of urban creativity: visually aware and radical object (Sowińska-Heim), unintentionally shaped landscape (Petri), and urban intervention which carried a promising artistic and social idea (Salwa).

Antoni Remesar in his text Twenty Years Working with Neighbours. Citizen Participation, Is It Possible? What We Have Learned in 20 Years reconstructs twenty years of cooperation between the Center de Recerca Polis (Polis Research Center) and the inhabitants of the peripheral areas of Barcelona: River Besòs (municipality of Sant Adrià de Besòs) and the Barcelona neighbourhoods of Baró de Viver and Bon Pastor. The article is a summary of research and participation activities; it emphasizes the importance of key aspects and achievements of these processes. It complements other studies conducted by the author and the Center de Recerca Polis research team which have been published in the magazine „On the w@terfront” and in the University of Barcelona publishing series COMUNICACIÓ ACTIVA/Ciudad. A complementary text by the same author, entitled The White Center. A First Step of The Civic Remembrance System in Bon Pastor (Barcelona), may be found in "Acta Universitatis 
Lodziensis. Folia Philosophica. Ethica - Aesthetica - Practica", no. 30 (2017). ${ }^{1}$ The broader aesthetic and theoretical context, which perhaps many readers would expect in connection with this problematic, can be found in Remesar's work entitled New Urban Decorum? City Aesthetics To and Fro. ${ }^{2}$

Complementary to the previous text is an article by Salvador Angosto, a Barcelonan activist, and former president of the Associació de Veïns i Veïnes del Bon Pastor Barcelona, entitled Mapping the History of a Territory: Bon Pastor (Barcelona) - Social Remembrance and Heritage Project. The author as a native born in a family resident in Casas de Baratas in the Bon Pastor neighbourhood in Barcelona describes complex stages of the formation of this neighbourhood from the bottom and from the inside. He also focuses on contemporary efforts to create the remembrance space system in this area. It is particularly important how the Center de Recerca Polis involves residents in research and how far this process of integration and exchange of knowledge and experience between researchers and residents is progressing. Particularly noteworthy here is the idea of the MUHBA (Museum of History of Barcelona), in which a special part located in the surviving rows of houses (Casas Baratas) will be devoted to reproducing the physical environment of the district and aesthetic forms of everyday life (document, furniture, household goods, etc.).

The next article: The Role of Visual, Semantic and Sensual Aspects of Architecture in Perpetuating the Memory of the Past - the New Synagogue of Mainz by Julia Sowińska-Heim, devoted to the eccentric shape of a new synagogue, at first glance seems to be a huge contrast to the expectations and values preferred in the process of the revival of the outskirts of Barcelona. However, considering that the temple by Manuel Herz Architekten emphasizes the importance of prayer as the main inspiration for the project, we again turn to the issue of deep experience, not only religious, but also the experience of the place.

The texts by Jakub Petri and Mateusz Salwa relate to Polish examples. They describe interesting, socially engaged projects, partly implemented, but abandoned or permanently changing. Petri in the article Urban Practices of Terrain Vague in Upper Silesia draws attention to the phenomenon of unintentional landscape arising in two areas of the Miners Valley ("Górnik Valley") and the current landscape park "Żabie Doły" (located in Upper Silesia in the municipalities of Bytom - Chorzów - Siemianowice). The unintentional landscape is an extraordinary fusion of side-effects of the post-industrial

\footnotetext{
${ }^{1}$ Antoni Remesar, Bibiana Crespo-Martin, "The White Center. A First Step of The Civic Remembrance System in Bon Pastor (Barcelona)," Acta Universitatis Lodziensis. Folia Philosophica. Ethica - Aesthetica - Practica, no. 30 (2017): 9-40.

${ }^{2}$ Antoni Remesar, "New Urban Decorum? City Aesthetics to and fro," in Aesthetic Energy of the City. Experiencing Urban Art And Space, eds. Agnieszka Gralińska-Toborek, Wioletta Kazimierska-Jerzyk (Łódź: Wydawnictwo Uniwersytetu Łódzkiego/Fundacja Urban Forms, 2016), 19-51.
} 
environment, the work of nature, which overcomes the effects of landscape damage, as well as grassroots activities of the local community. It is particularly interesting how the author develops the idea of Catalan architect and philosopher Ignasi Sola-Morales, who coined the term terrain vague to describe a specific class of empty, abandoned areas in a city frame. A special opportunity for aesthetic experience - as Petri suggests - is created where we do not expect it; moreover, it is created from such components that seemed irretrievably lost.

Mateusz Salwa also writes about the everyday and egalitarian space of aesthetic experience. In his text The Everyday Aesthetics of Public Space he focuses - unlike the previous article - on intentional shaping of the urban environment. The object of analysis is the transformation of Grzybowski Square in Warsaw. Salwa discusses the Oxygenator installation created by Joanna Rajkowska for this place, the intention of which was to offer people an ordinary, unspectacular place where residents could meet in a "healthy atmosphere". The installation lasted only two months after which it was replaced by a more "polished" and elegant look, matching the capital metropolis. The article ends by reflecting on the fact that community experience does not have to be a universal experience. Values, which at the same time offer something to the city, may result in the same extent from the understanding of its historical and functional tissue, as well as from following the ways of inhabiting it.

As the questions of the negative effects of aestheticization processes and the idea of a good living are latently present in all texts, the issue is closed by two review articles concerning books published in Polish: anthology Między etyka a estetyka. Rozważania nad problemem estetyzacji [Between Ethics and Aesthetics. Reflections on the Problem of Anesthetization], eds. Kinga Kaśkiewicz, Rafał Michalski, Tomasz Siwiec (Toruń: Wydawnictwo Naukowe Uniwersytetu Mikołaja Kopernika, 2017) and a collection of lectures by Bohdan Dziemidok entitled Filozofia i sztuka życia [Philosophy and Art of Life] (Lublin: Wydawnictwo Uniwersytetu Marii Curie-Skłodowskiej, 2017).

Wioletta Kazimierska-Jerzyk Agnieszka Rejniak-Majewska 